\title{
Rural India Development: Strategies and Improvements
}

\author{
Suraj P. Mishra \\ Site Enginner \\ JSV Infrastructure PVT LTD \\ Mumbai, Maharashtra, India
}

\author{
Vicky N. Gupta \\ Graduation Student, \\ Department of Civil Engineering \\ Thakur College of Engineering and Technology \\ Mumbai, Maharashtra, India
}

\author{
Pooja N. Gupta \\ Graduation Student, \\ B. L. Amlani College Of Commerce \& Economics \\ Mumbai, Maharashtra, India
}

\begin{abstract}
Around $63 \%$ people of India depend on agriculture. This agricultural production and consumption process is a key factor in developing the Indian economy. - The increase in farm productivity for achieving rapid economic transformation and increasing the profits to the farmers and to increase the household outputs of the selected agricultural products are the major objectives of this paper. The present article majorly focuses on various rural region development strategies in field of agriculture growth, beginning from management of land, labor and natural resources to the effective harvesting, pre-processing methods for crops and effective marketing strategies to be followed for consistent growth.
\end{abstract}

Keywords: Rural India development, Agricultural products, rural development strategies, Indian economy.

\section{INTRODUCTION}

The policy makers in most of the developing economies recognize the importance of rural areas and have been implementing a host of programs and measures to achieve rural developmental objectives. While some of these countries have achieved impressive results, and others have failed to make a significant dent in the problem of persistent rural under development. The rural India's agricultural production \& consumption process plays an essential role in developing the Indian economy. Agriculture and agro processing accounts for 30-60\% of Gross Domestic Product (GDP) in developing countries 63 $\%$ of population resides in rural areas only. With rapid urbanization and globalisation rural people depends mostly on agriculture. India started producing about 700 million tonnes of biological materials per year including food grains, fruits, oilseeds, vegetables, milk, eggs, tea, coffee, fibre crops, and forest products and so on. Because of its socio economic impact and financial status specifically on employment and income generation, agro processing is now known as the sunrise sector of the Indian economy. The common and similar agro-processing industries includes paper making units, hand pounding units for rice, bullock operated sugarcane crushers, water power driven flour, bullock driven oil ghanies, spinning wheels and handloom units for weaving etc. The rural areas are consuming a large number of industrial and urban manufactured products.

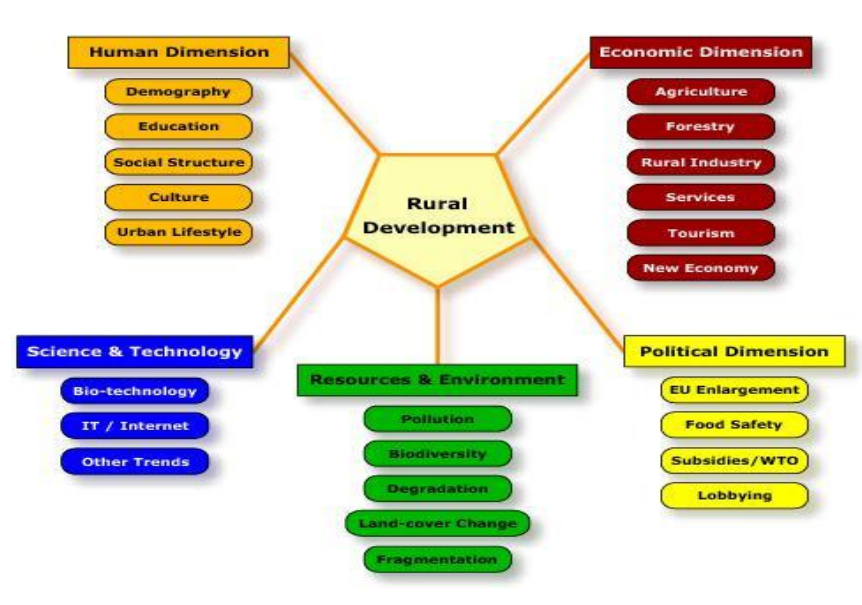

Fig(i): Rural development.

Source: Royal Commission of Canada, 2003

The essential areas for the rural development are

I. Economic dimension

II. Human dimension

III. Science \& Technology

IV. Resources and Environment

V. Political dimension.

\section{NEED FOR RURAL DEVELOPMENT}

I. To raise the quality of life \& improve the environment in rural areas.

II. To reduce the urbanization effect.

III. To improve of Indian economy.

IV. For the proper and smart management of natural resources like land, water for agricultural production and processing.

V. To produce and process variety of food products through agriculture.

VI. To improve and increase profits for farmers.

The implementation of rural India development strategies will utilise \& develop existing institutional, management and funding mechanisms and schemes to focus on the expenditure of government in the three spheres to more be effective and efficient to the needs and opportunities. So there is a great and essential need to develop the rural areas 
for the improvement of Indian economy. The major objectives of the RDS are to increase farm productivity and profitability, for achieving rapid economic transformations, to increase and improve household outputs of the selected agricultural products, and to promote value addition and ensure a stable market for these agricultural products.

\section{RDS (STRATEGIES)}

The effective rural developments strategies that must be followed are

1. The Provision of support to the farmer Groups and the associations in order to build their capacity and supporting the farmer unions.

2. By adopting the localized way of distributing the agricultural products.

3. The water management for agricultural production by the utilisation of sprinklers and drips.

4. Involvement of private sector companies for processing \& marketing.

5. By proper and effective communication \& quality maintenance.

6. Enhancing and improving rural micro finance services \& provision for subsidisation for crops.

7. Strategies for the provision of utilisation of technology by farmers.

8. Liberalization of the Markets and the Pricing Structures.

9. All weather roads to the rural habitations.

10. Improved economic utilization of agricultural residues, by-products \& the recycling of wastes by the establishment of separate recycler plants at the village levels by the support of government and local gram panchayats.

11. Enhancement of linkages and tie-ups of the farmer groups with processors and the buyers for increasing the profits to the farmers.

12. Pests and disease control with the utilisation of improved seeds, Bio Fertilizers, Herbicides, and Bio Pesticides.

13. Usage of advanced equipment and machineries that constitutes the technology for the plantation and for the harvesting of the crops that leads to decrease in the labour cost and expenses.

14. Enhancement of the agricultural productivity.

15. Research \& Development of the agro processing technologies for the crops.

16. Provision of Support to agriculture related industries.

17. Establishment of farmer care and guidance centres.

18. Analysis of complete Agricultural trade and statistics including Tree crops, consumption data, diseases and disease control data, statistics on agricultural products processing \& marketing etc.

19. Increasing utilisation of the organic farming.

Because of in use of pesticides and fertilizers by the farmers, scientists have been advising the organic products. The agricultural products, are those products that are produced through organic farming termed as organic products. In today's world market these organic products are having high demand day to date. So, there is an overwhelming need to follow the organic farming by the Indian farmers and produce the organic foods and export to the other countries for the propitiation. Worldwide, there was an increase in organic farming land, $11 \%-40 \%$ from 1990 to 2010. Shown in graph.1.

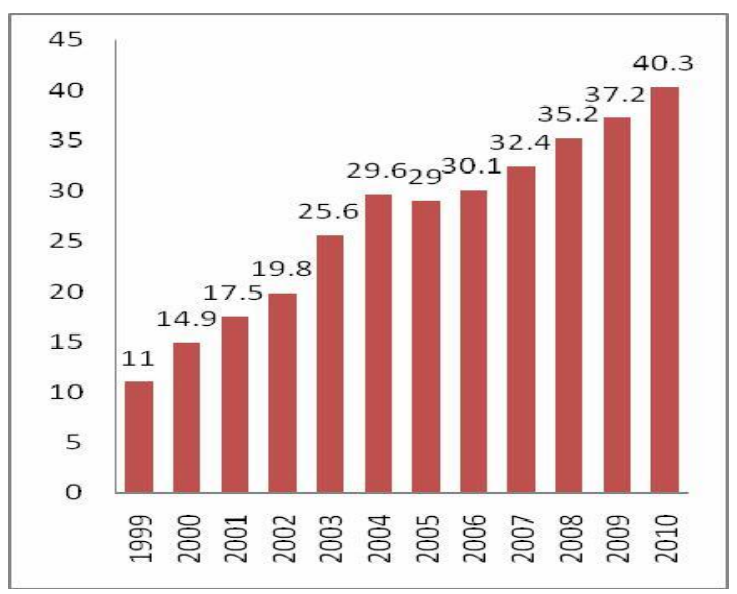

Graph (i): Development of world organic agricultural land (1999 - 2010)

Source: S-CEL1999 - 2010

20. By conducting and organizing the camps / programs at the rural areas regarding the rural development and agriculture.

21. Establishment of separate teams and committees for the rural development by the central government with special packages and schemes.

22. Maintenance of cleanliness at village level.

23. By providing public transport facilities to the rural people.

24. Increasing the interactions with the agricultural experts for gaining more productivity and profits.

These are the different rural India development strategies.

\section{RURAL MARKETING}

Rural marketing basically deals with delivering of the manufactured or the processed inputs or the services to rural India producers. Rural Marketing includes input from manufacturers, dealers, farmers, government agencies and traders. Thus, to do the promotion of their brands, they are exploiting social and cultural values. Increasing specialization in the farming sector has lead the marketers to this strategy.

\section{CHALLENGES FOR RURAL DEVELOPMENT}

I. Developing rural areas is a long and time consuming process.

II. There is no doubt that the most of the rural people depend on agriculture and that is a risky business.

III. Sustainability in economic growth and diversification.

IV. Funding from the Government and institutional development.

V. Agricultural employment has started to decline and boost is required where replacement employment is essential. 
VI. Lack of appropriate technology \& beneficiary participation is must.

\section{CONCLUSION}

More than $63 \%$ of the Indian population resides in the rural areas and most of the rural people depend on agriculture and agricultural related industries. So there is an overwhelming need to follow the effective rural development strategies for improving the quality of life in the rural areas, self-employment to the rural people and raising the profits to the farmers to improve the Indian economy. The most challenging task is to see whether the funds have been properly utilized and managed. The implementation is to be properly checked to bring the required result in the appropriate time. People in rural areas should have the same quality of life as is enjoyed by people living in sub urban and urban areas.

\section{REFERENCES}

[1] A. Matthew, Renkoski, Marketing Strategies of Biotechnology Firms: Implications for U.S, Agriculture Journal of Agricultural and Applied Economics, vol. 29 (1): 123 -128, 1997.

[2] B. Raymond, Regional and Rural Development Strategies in Canada, The Search For Solutions Royal Commission on Renewing and Strengthening Our Place in Canada, 2003.

[3] C. Dankers, and P. Liu, FAO: Environmental and social standards, certification and labelling for cash crops, Commodities and Trade Technical Paper No. 2. Rome, 2003.

[4] E. Wynen, Impact of organic guarantee systems on production and trade in organic products. fao-ifoam-unctad International Task Force on Harmonization and equivalence in organic agriculture, the Third Meeting, Rome 17 - 19, 2004.

[5] G. V. Fox, G. Adamowicz, Debailleul and P. Thomassin, Agriculture and the Environment: Economic Dimensions of Sustainable Agriculture. Canadian Agricultural Economics and Farm Management Society, Occasional Paper No.1, 1990.

[6] Harmonization and equivalence in organic agriculture, the Third Meeting, Rome 17-19.

[7] J. D. House, The New Regional Development: Is Rural Development a Viable Option in Newfoundland and Labrador, Newfoundland Studies, vol. 17 (1): 11-31, 2001.

[8] J. Dumanski, G. Coote, Lucerek and C. Lok, Soil Conservation in Canada, Journal of Soil and Water Conservation, Vol. 41, 1986.

[9] J. S. Donald, Rural Redevelopment in Canada: The Case of Northeast New Brunswick. Journal of Rural Studies, vol.5 (2): 185-197, 1992.

[10] J. Stabler, M. Olfert, and M. Fulton, The Changing Role of Rural Communities in an Urbanizing World, University of Regina, 1992.

[11] K. Hamilton, Resource Accounting: Issues and Problems Related to Agriculture, Canadian Journal of Agricultural Economics, vol. 39 (4), Part 1, 1991.

[12] M. Moraka, Decentralisation and participation for sustainable rural Development, University of Pretoria South Africa, 2000.

[13] Ministry of Agriculture, Animal Industries and Fisheries, Programme for Targeting Commercial Agriculture Production in Uganda, Ref. No. 104. Uga. 26/110 (31), 1998.

[14] Ministry of Agriculture, Animal Industry and Fisheries operationalisation of the rural development strategy for increased agricultural productivity, Uganda, 2005.

[15] P. Santacoloma, Organic Certification Schemes: managerial skills and associated costs. Synthesis report from case studies in the rice and vegetable sectors. AGSF Occasional paper, 16, 2007.

[16] R. C. Crook, and J. Manor, Democracy and Decentralization in South Asia and West Africa: Participation, Accountability and Performance, Cambridge: Cambridge University Press, 1998.

[17] R. Gray, Economic Measures of Sustainability, Canadian Journal of Agricultural Economics, vol. 39 (4), 1991.
[18] R. Gray, and H. Furtan, Improving Gains from Trade in Wheat for the Canadian Economy, Improving Agriculture Trade Performance under the GATT. Becker, Gray and Schmitz eds, 1992.

[19] R. J. Macrae, S. B. Hill, J. Hennings, and A. J. Bentley, Policies, Programs and Regulations to Support the Transition to Sustainable Agriculture in Canada, American Journal of Alternative Agriculture, vol. 5 (2), 1990.

[20] R. P. Kachru, Agro Processing Industries in India - Growth, Status and Prospects, status of farm mechanization in India Indian Council of Agricultural Research, New Delhi, pp. 114$126,2002$.

[21] S. Gopalakrishnan Iyer, ICT in marketing Media for rura marketing India, i4d. www.i4d.csdms.in, 2006

[22] S. S. Batie, Sustainable Development: Concepts and Strategies, Sustainable Agricultural Development: The Role of International Cooperation. IAAE, University of Oxford, 1992.

[23] The South African Governmentthe integrated sustainable rural development strategy (isrds), 17 November, 2000.

[24] W. B. Magrath, Comment on Regional Sustainable Development by Nijkamp, Proceedings World Bank Conference on Development Economics, World Bank, 1991. 